\title{
Self-Cured High Strength Concrete-An Experimental Study
}

\author{
Dr. T. Muralidhara Rao \\ Professor, CVR College of Engineering/Civil Engg. Department, Hyderabad, India. \\ Email: tmuralidhararao@gmail.com
}

\begin{abstract}
The effect of elevated temperature and durability studies is studied on fifty-four numbers of self-cured high strength concrete cubes of $100 \mathrm{~mm}$ size with ultrafine mineral admixture, Alccofine 1203. Optimum dosage of internal curing compound and Alccofine used is $0.25 \%$ and $10 \%$ respectively. Non-destructive, elevated temperature, and durability studies are conducted on the specimens. Between the temperatures $100^{\circ} \mathrm{C}$ to $900^{\circ} \mathrm{C}$, the percentage of loss in weight is found to be decreased. But, compressive strength is increased at $300^{\circ} \mathrm{C}$ and decreased at higher temperatures. The weight and compressive strength are increased for the cube specimens due to the specimens immersion in Sulphate, Chloride and Alkali solutions and Sea water respectively.
\end{abstract}

Index Terms: Elevated temperature, non-destructive tests, Durability tests, Weight, Compressive strength.

\section{INTRODUCTION}

\section{A.Self-Curing}

In conventional curing, curing happens 'from external to internal'. In self-curing, curing happens 'from internal to external' through the internal reservoirs. Internal curing reduces the water evaporation from concrete and increases the water retaining capacity of the concrete. The difference between conventional and internal curing is presented in Fig.1.

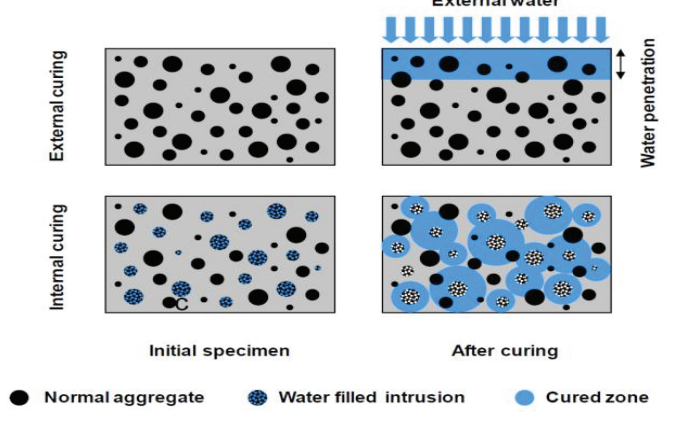

Figure 1. Conventional (external) curing and internal curing

As per ACI-308-2013, "Internal curing refers to the process by which the hydration of cement occurs because of the availability of additional internal water that is not part of the mixing water".

\section{B.Necessity of self curing}

- In high strength concrete, the depth that the external water can penetrates is limited due to the low watercement ratio of concrete. In such a case, Self-curing (SC) of concrete solves the problem of degree of cement hydration because self-curing enables the water to distribute more equally throughout the cross-section.

- $\mathrm{SC}$ is a good solution where there is an acute shortage of water.

- $\mathrm{SC}$ is a good solution for curing vertical members, inclined members, extreme corner locations, top-most members/areas where normal curing is difficult.

- $\mathrm{SC}$ is a right choice for curing of high-rise structures.

- $\mathrm{SC}$ is an appropriate alternative when the dependency on unskilled labour for conventional curing is high.

- $\mathrm{SC}$ is preferable in hot weather regions where large quantity of water is required for curing owing to the evaporation losses.

- $\quad \mathrm{SC}$ is advisable when the cost of obtaining water with the desired quality is expensive.

- $\mathrm{SC}$ is desirable when it is required to reduce the cost of operations, quicker turn-around time in precast plants.

\section{Significance of present study}

Now-a-days, the foremost challenge in construction field is the lack of availability of water. Construction industry must switch over to alternate curing methods like self-curing method for the sustainable development of the environment. Self-cured concrete does not require water for curing hence, there will be no excess usage of water. Therefore, an attempt is made in the present paper to achieve the required strength and durability of high strength concrete by internal curing with suitable admixtures and the effect of elevated temperatures on self-cured high strength concrete and conventionally cured high strength concrete.

\section{LITERATURE REVIEW}

The water movement from internal curing agents into hydrating cement paste with a low water-cement ratio was studied and observed that the amount of water first received by the paste in the proximity of the Super-absorbent Polymer can be redistributed later to a large volume of hardening paste when the permeability becomes very low[1]. Characterization of a super-absorbent polymer was studied by determining compressive strength, split tensile strength and flexural strength of the concrete containing SAP and compared with conventionally cured concrete[2]. Three different curing techniques were used and the variation of compressive strength of medium strength and self-compacted concrete was studied. Immersion curing method gave maximum compressive strength. Internal curing with Polyethylene Glycol (PEG) gave only 5\% lesser compressive strength than immersion curing[3]. Workability and strength characteristics of Normal Strength and High 
Strength Concrete with Polyethylene Glycol and S orbital were studied and compared with the conventionally cured concrete of M20, M30 and M40, M60, M70 and M80 grades [4]. The variation of weight, compressive strength, flexural strength and split tensile strengths of concrete cubes was investigated with the use of PEG4000 and PEG200 at 0.1\%, $0.5 \%, 1 \%$ in M70 grade concrete. Durability tests were also conducted [5]. Strength characteristics of M20 concrete with PEG400 were compared with the conventionally cured concrete at 3days, 7days, 14 days and 28 days [6]. Strength and workability tests were conducted on M20 and M25 grade concrete using PEG600 at $0.5 \%, 1 \%, 1.5 \%$, and $2 \%$ [7]. Strength properties of M20 grade concrete were studied using PEG400 at different percentages [8]. Effect of solid Paraffin wax on the strength properties of concrete was studied and compared with the properties concrete made with Master Rheo-build [9].

\section{EXPERIMENTAL PROGRAMME}

\section{A. Materials Used}

The specific gravity of ordinary Portland Cement (53 grade) used is 3.10.The specific gravity of sand (fine aggregate) used is 2.65 . The specific gravity of coarse aggregate used is 2.70. Potable water is used for making the concrete. The Superplasticizer used is Master Glenium ACE30JP(at $1.2 \%$ by weight of binder). The supplementary cementitious material used is Alccofine1203. The internal curing compound used is Polyethylene Glycol 8000.The mix proportions used for the preparation of high strength concrete are1:0.556:1.629:0.25.

\section{B. Elevated Temperature Studies}

Influence of temperature on Compressive strength, Weight loss and Durability properties of cubes is studied in this paper. Duration of temperature is 02 hours and varied from $100^{\circ} \mathrm{C}$ to $900^{\circ} \mathrm{C}$ at an interval of $100^{\circ} \mathrm{C}$ as presented in Fig.4.

Air-cooled cubes Ultrasonic pulse velocity is measured using Portable Ultrasonic Non-destructive Digital Indicating Tester [10] and the quality of concrete is studied.

\section{Ultrasonic Pulse Velocity (UPV)}

For cubes with high density, homogeneity and uniformity, higher velocities values are observed. In case of poor quality cubes, lower velocities are observed. The test results of Ultrasonic pulse velocity are presented in Fig. 2.

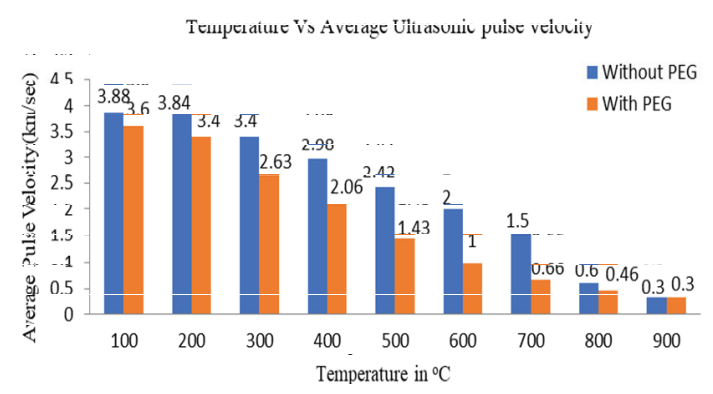

Figure 2.Ultrasonic pulse velocity of cubes

\section{Percentage loss in weight}

The percentage loss in weight of cubes without PEG8000is calculated at different temperatures and presented in the Fig.3. The percentage loss in weight of cubes is found to be increased up to $900^{\circ} \mathrm{C}$.

Similarly, the percentage loss in weight of cubes with PEG8000 is calculated at different temperatures and presented in the Fig.3. The percentage loss in weight of cubes is found to be increased up to $900^{\circ} \mathrm{C}$.

The comparison of percentage weight loss of cubes without and with PEG8000 at different temperatures is presented in Fig.3.

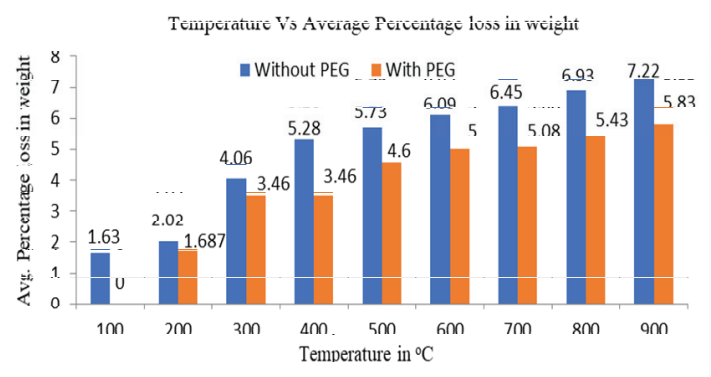

Figure 3. Weight loss of cubes without and with PEG8000

\section{E. Compressive Strength}

Compressive strength of $100 \mathrm{~mm}$ cubes with different dosages of PEG8000 is presented in Fig.4. Total cubes cast (with different dosages of PEG8000 from $0.1 \%$ to $2.25 \%$ )are thirty-four. From Fig.3, the optimum dosage of PEG8000 is found to be $0.25 \%$.

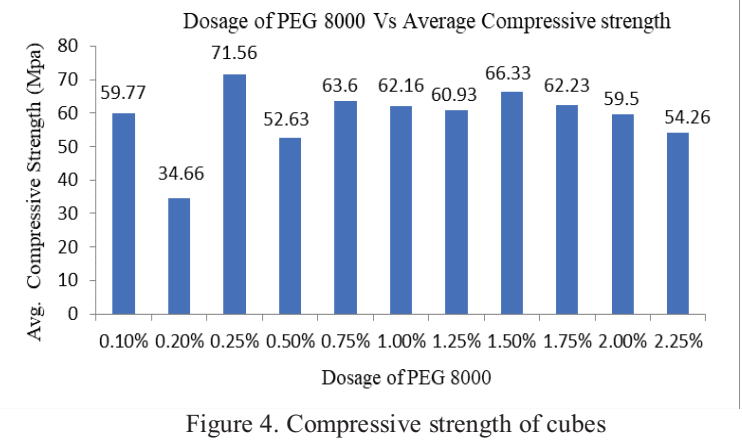

Twenty-seven $100 \mathrm{~mm}$ cubes are cast for studying the weight loss and compressive strength at room temperature. Twenty-seven more cubes of $100 \mathrm{~mm}$ size are tested to study the variation in the weight loss and compressive strength cubes before and after subjecting to the elevated temperatures. After 28 days of conventional curing, cubes without PEG8000 are air dried and tested to $100^{\circ} \mathrm{C}, 200^{\circ} \mathrm{C}$, $300^{\circ} \mathrm{C}, 400^{\circ} \mathrm{C}, 500^{\circ} \mathrm{C}, 600^{\circ} \mathrm{C}, 700^{\circ} \mathrm{C}, 800^{\circ} \mathrm{C}$ and $900^{\circ} \mathrm{C}$ temperature for 02 hours in a high Temperature Furnace of $1000^{\circ} \mathrm{C}$ capacity. No visible cracks are observed up to $300^{\circ} \mathrm{C}$. Cracks are observed in the specimens when tested to $400^{\circ} \mathrm{C}$ and $500^{\circ} \mathrm{C}$. Pronounced cracks are seen on the surface of the cubes at $600^{\circ} \mathrm{C}, 700^{\circ} \mathrm{C}, 800^{\circ} \mathrm{C}$ and $900^{\circ} \mathrm{C}$ respectively. Upto $600^{\circ} \mathrm{C}$, no change in the colour of cubes is observed. At $700^{\circ} \mathrm{C}$, the color of cubes changed to pink/red. Beyond 
$700^{\circ} \mathrm{C}$, the color of cubes changed to grey. Cubes are tested for residual compressive strength under Automatic Compression Testing Machine.

Residual compressive strength of cubes without PEG8000 is shown in Fig.5. The Compressive strength of concrete is decreased, when the cube specimens are exposed to a temperature from $100^{\circ} \mathrm{C}$ to $200^{\circ} \mathrm{C}$. The Compressive strength is found to be increased at $300^{\circ} \mathrm{C}$. From $400^{\circ} \mathrm{C}$ to $500^{\circ} \mathrm{C}$, there is a nominal decrease in the compressive strength. From $600^{\circ} \mathrm{C}$ to $900^{\circ} \mathrm{C}$, an increase in the percentage decrease is observed in the compressive strength. At $600^{\circ} \mathrm{C}$, the average percentage decrease in compressive strength is $26.81 \%$. At $700^{\circ} \mathrm{C}$, the average percentage decrease in compressive strength is $32.15 \%$. At $800^{\circ} \mathrm{C}$, the average percentage decrease in compressive strength is $52.08 \%$. At $900^{\circ} \mathrm{C}$, the average percentage decrease in compressive strength is $69.83 \%$. The decrease in compressive strength between $600^{\circ} \mathrm{C}$ and 800 may be due to the decomposition of C-S-H gel and dehydration of calcium hydroxide $(\mathrm{CH})$ into free lime. Decomposition of calcium carbonate and the loss of free water may be the reason for the decrease in compressive strength of concrete at $900^{\circ} \mathrm{C}$.

Comparison of residual compressive strength of cubes without and with PEG8000 is presented in Fig.5.Compressive strength of concrete is decreased, when the cubes are exposed to a temperature from $100^{\circ} \mathrm{C}$ to $200^{\circ} \mathrm{C}$. The Compressive strength is found to be increased at $300^{\circ} \mathrm{C}$. The increase in strength at $300^{\circ} \mathrm{C}$ may be due to the increase in the surface forces among the gel particles. From $400^{\circ} \mathrm{C}$ to $500^{\circ} \mathrm{C}$, an increase in the decrease of compressive strength is observed. From $600^{\circ} \mathrm{C}$ to $900^{\circ} \mathrm{C}$, the compressive strength is decreased.

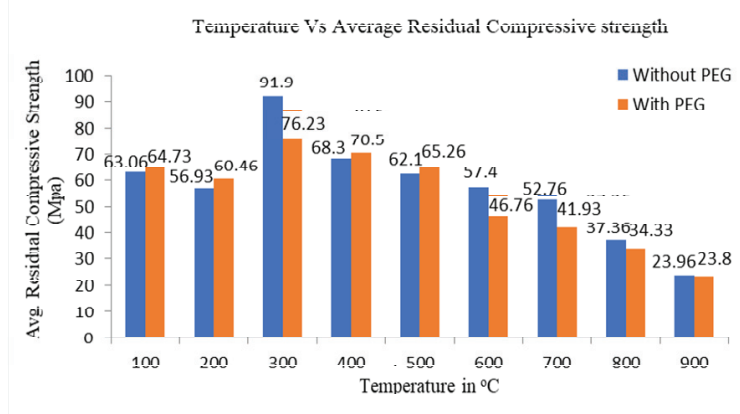

Figure 5.Average residual compressive strength of Cubes without and with Polyethylene Glycol 8000

\section{F. Sulphate Test}

Three cubes of $100 \mathrm{~mm}$ size are cured in water for 28 days. Then the cubes are dried at $50^{\circ} \mathrm{C}$ for 24 hours and weights are taken before placing in the Sulphate solution (2.5\% $\mathrm{Na}_{2} \mathrm{SO}_{4}$ and $2.5 \% \mathrm{MgSO}_{4}$ by weight of water).After the prescribed period, the average percentage loss in weight of cubes is calculated at 7, 14, 28 and 56 days and shown in Fig. 6.

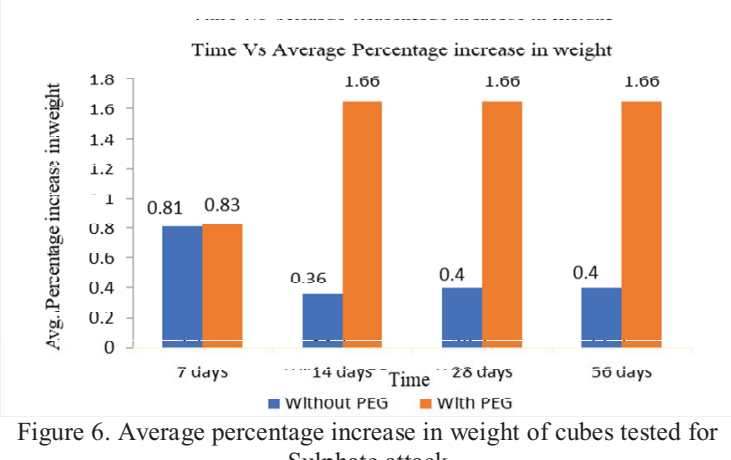
Sulphate attack

\section{G. Chloride Test}

Three cubes of $100 \mathrm{~mm}$ size are cured in water for 28 days. Then the cubes are dried at $50^{\circ} \mathrm{C}$ for 24 hours and weights are taken before placing in the Sodium chloride solution $(5 \%$ of $\mathrm{Nacl}$ by weight of water).After the prescribed period, the average percentage loss in weight of cubes is calculated at 7, 14, 28 and 56 days and shown in Fig.7.

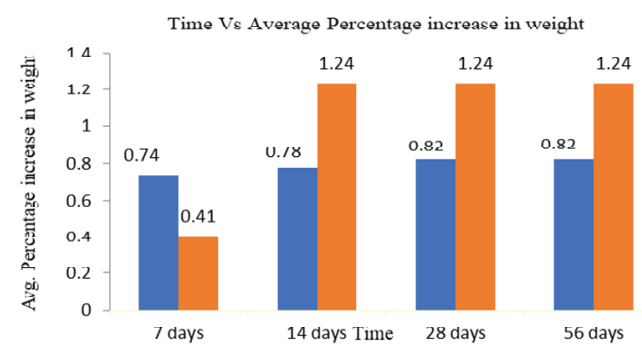

Figure 7. Average percentage increase in weight of cubes tested for Chloride attack

\section{H. Alkali Test}

Three cubes of $100 \mathrm{~mm}$ size are cured in water for 28 days. Then the cubes are dried at $50^{\circ} \mathrm{C}$ for 24 hours and weights are taken before placing in the Sodium hydroxide solution $(5 \%$ of sodium hydroxide solution by weight of water).After the prescribed period, the average percentage loss in weight of cubes is calculated at 7, 14, 28 and 56 days and shown in Fig.8.

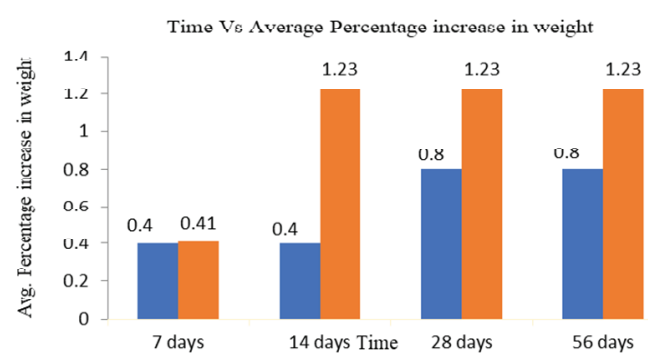

Figure 8. Average percentage increase in weight of cubes tested for $\mathrm{NaOH}$ attack

\section{Sea Water Test}

Three cubes of $100 \mathrm{~mm}$ size are cured in water for 28 days. Then the cubes are dried at $50^{\circ} \mathrm{C}$ for 24 hours and 
weights are taken before placing in the sea water $(5 \%$ of Sea water solution).After the prescribed period, the average percentage loss in weight of cubes is calculated at 7, 14, 28 and 56 days and shown in Fig.9.

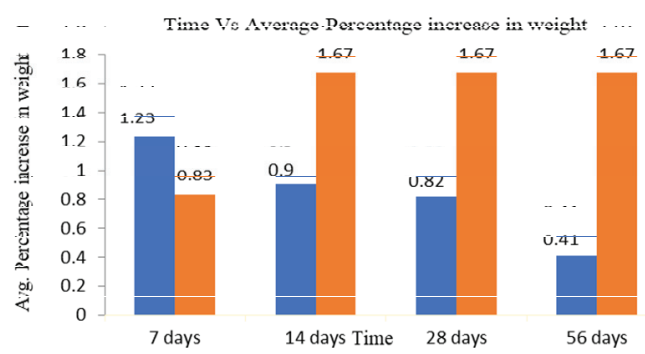

Figure 9. Average percentage increase in weight of cubes tested for Sea Water attack

\section{J. Pulse Velocity}

The average pulse velocity of cubes without and with PEG8000 is presented in Fig. 10.

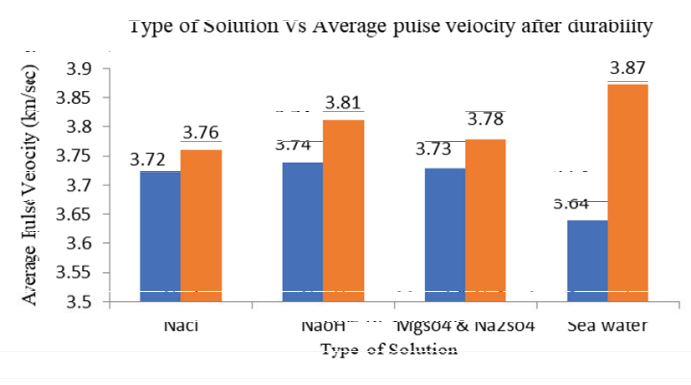

Figure 10. Average pulse velocity cubes

The interfacial transition zone thickness variation and the decrease in the voids ratio of hardened concrete may be attributed to the increase in weight and compressive strength of the cubes.

\section{K. Sorptivity Test}

$100 \mathrm{~mm}$ concrete cubes are placed in the oven at a temperature of $50^{\circ} \mathrm{C}$ for 03 days, before placing cubes in contact with water[11]. Sorptivity coefficient is calculated as $1.5873 \times 10^{-4} \mathrm{~mm} / \mathrm{min}^{0.5}$. Sorptivity values are presented in Fig. 11.

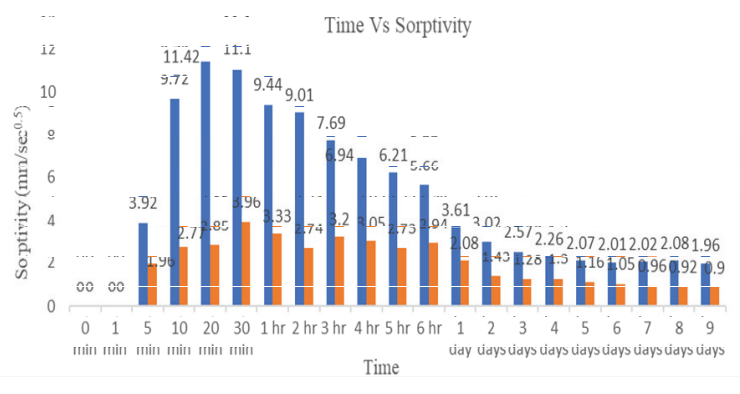

Figure11. Sorptivity of concrete cubes without and with PEG8000

\section{Discussions AND Conclusions}

Self-curing of concrete using PEG8000 is found to be a good alternative for conventional curing of concrete. Discussions and conclusions are presented below.

$1.10 \%$ replacement of cement replacement by Alccofine1203 is found be an optimum percentage forobtaining an average compressive strength of 79.93MPa without PEG8000.

2. Optimum dosage of PEG8000 is found to be $0.25 \%$ by weight of binder forobtaining an average compressive strength of $71.56 \mathrm{MPa}$. The percentage of difference between the compressive strengths achieved without and with PEG8000 was $10.47 \%$.

3. Without PEG8000, the average Compressive Strength of concrete cubes at 56 days of curing in $\mathrm{Nacl}, \mathrm{NaoH}$, $\mathrm{MgSO}_{4}$ plus $\mathrm{Na}_{2} \mathrm{SO}_{4}$ solutions and Sea water is found to be $91.83 \mathrm{MPa}, 94.6 \mathrm{MPa}, 86.93 \mathrm{MPa}$ and $89.10 \mathrm{MPa}$ respectively. Without PEG8000, the average Compressive Strength of concrete cubes before 56 days of curing was 69.71MPa, $79.93 \mathrm{MPa}, 63.55 \mathrm{MPa}$ and $78.40 \mathrm{MPa}$. The percentage increase in compressive strength is found to be $31.73,18.35,36.78$ and 13.64. The increase in compressive strength may be due to the increase in density of concrete cubes.

4. Compressive Strength of concrete cubes with PEG8000 after 56 days of curing in $\mathrm{Nacl}, \mathrm{NaoH}, \mathrm{MgSO}_{4}$ plus $\mathrm{Na}_{2} \mathrm{SO}_{4}$ solutions and Sea water is found to be $75 \mathrm{MPa}, 77$ $\mathrm{MPa}, 72.56 \mathrm{MPa}$ and $73.33 \mathrm{MPa}$ respectively. The average Compressive Strength of high strength concrete cubes without PEG8000 before 56 days was $71.3 \mathrm{MPa}$, 71.2 $\mathrm{MPa}, 69.2 \mathrm{MPa}$ and $70.73 \mathrm{MPa}$. The percentage increase in compressive strength was found to be 5.18 , 3.77, 4.85 and 3.67.

5. Initial rate of water absorption of high strength concrete cubes without and with PEG8000 is not linear due to the increase in water absorption whereas the secondary rate of absorption is linear due to less water absorption. More water absorption may be attributed to the precondition of the concrete cube specimens at a temperature of $100^{\circ} \mathrm{C}$ for 24 hours. Less water absorption during 1day-7days may be attributed to the less pore space available after the initial absorption period of $1 \mathrm{~min}$-6hour.

6. Compressive strength of $100 \mathrm{~mm}$ cubes after two hours at $300^{\circ} \mathrm{C}$ is found to be increased by $18.55 \%$. The increase in compressive strength at $300^{\circ} \mathrm{C}$ may be due to the increase in surface forces between gel particles because of the removal of moisture content. After critical temperature of $300^{\circ} \mathrm{C}$, the compressive strength of cubes is decreased considerably upto $900^{\circ} \mathrm{C}$. Similar trend is observed for concrete cubes with PEG8000.

As per the discussions, the use of PEG8000is recommended for the preparation of high strength concrete in the water scarce areas or where potable water is not available for the preparation of concrete. 


\section{REFERENCES}

[1] Mateusz Wyrzykowski, PietroLura, Francesco Pesavento, DariuszGawin, 'Modeling of water migration during internal curing with Superabsorbent Polymers', Journal of Materials in Civil Engineering,vol. 24, Issue 08, August2012.

[2] Amal Francis k, Jino John, 'Experimental investigation on mechanical properties of self-curing concrete', International Journal of Emerging Trends in Engineering and Development, vol.2, Issue 3, March 2013.

[3] ] Nanak, J., Pamnani, Verma, A.K., Bhatt, D.R.,' comparison of compressive strength of medium strength self-compacted concrete by different curing techniques', International Journal of Engineering Trends and Technology,vol. 4,Issue 5, May2013.

[4] Vedhasakthi, K., Saravanan, M.,' Development of normal strength and high strength self-curing concrete using Super Absorbing Polymers and comparison of strength characteristics', International Journal of Research in Engineering and Technology, vol. 03, Issue 10, October 2014.

[5] Bala, K., Subramanian, Siva, A., Swaminathan, S.,Arul, M.G., Ajin,' Development of high strength self-curing concrete using Super Absorbing Polymer', International Journal of Civil, Environmental, Structural, Construction and Architectural Engineering,vol. 09, Issue 12, 2015.

[6] Siddiqui Mohammed Junaid, 'An experimental investigation on internally cured concrete', International Journal on Recent and Innovation Trends in Computing and Communication,vol. 04, Issue 4, April 2016.

[7] Mohammed, V., Shafeeque, Sanofar, P.B., Praveen, K.P., Jithin Raj, Nikhil,V.P., Gopikrishna, P.M., 'Strength comparison of self-curing concrete and normal curing concrete', SSRG International Journal of Civil Engineering, vol. 3 Issue 3, March 2016.

[8] Basil, M., Joseph, 'Studies on properties of self-curing concrete using Polyethylene Glycol', IOSR Journal of Mechanical and Civil Engineering, December-2017.

[9] Mohammed Bilal, Ambikapathi, 'Experimental study on internal curing of high strength concrete', International Journal of Engineering Sciences \& Research Technology, January-2017.

[10] IS:13311(Part-1)-1992, "Non-Destructive Testing of Concrete-Methods of Test".

[11] ASTM:C1585-04, "Standard Test Method for measurement of rate of absorption of water by hydraulic cement concretes", PP 1-5. 